\title{
Low-protein solid feed improves the utilization of milk replacer for protein gain in veal calves
}

\author{
H. Berends, ${ }^{\star 1}$ J. J. G. C. van den Borne, ${ }^{\star}$ S. J. J. Alferink, ${ }^{\star}$ C. G. van Reenen, $†$ E. A. M. Bokkers, $\neq$ \\ and W. J. J. Gerrits* \\ *Animal Nutrition Group, Wageningen University, PO Box 338, 6700 AH Wageningen, the Netherlands \\ †Livestock Research, Animal Sciences Group, Wageningen University and Research Centre, PO Box 65, 8200 AB Lelystad, the Netherlands \\ $\ddagger$ Animal Production Systems Group, Wageningen University, PO Box 338, $6700 \mathrm{AH}$ Wageningen, the Netherlands
}

\section{ABSTRACT}

This study was designed to quantify the contribution of low-protein solid feed (SF) intake, in addition to milk replacer, to protein and energy retention in veal calves. Because of potential interactions between milk replacer and SF, occurring at either the level of digestion or postabsorption, this contribution might differ from that in calves fed either SF or milk replacer alone. Forty-eight Holstein Friesian male calves, $55 \pm 0.3 \mathrm{~kg}$ of body weight (BW), were divided across 16 groups of 3 calves each. Groups were assigned randomly to 1 of 4 incremental levels of SF intake: 0, 9, 18, or 27 $\mathrm{g}$ of $\mathrm{DM}$ of $\mathrm{SF} / \mathrm{kg}$ of $\mathrm{BW}^{0.75}$ per day. The SF mixture consisted of $25 \%$ chopped wheat straw, $25 \%$ chopped corn silage, and $50 \%$ nonpelleted concentrate (on a DM basis). Each group was housed in a respiration chamber for quantification of energy and $\mathrm{N}$ balance at each of $2 \mathrm{BW}$ : at $108 \pm 1.1 \mathrm{~kg}$ and at $164 \pm 1.6 \mathrm{~kg}$. The milk replacer supply was $37.3 \mathrm{~g}$ of $\mathrm{DM} / \mathrm{kg}$ of $\mathrm{BW}^{0.75}$ per day at $108 \mathrm{~kg}$ of $\mathrm{BW}$ and $40.7 \mathrm{~g}$ of $\mathrm{DM} / \mathrm{kg}$ of $\mathrm{BW}^{0.75}$ per day at $164 \mathrm{~kg}$ of BW, irrespective of SF intake. Within a chamber, each calf was housed in a metabolic cage to allow separate collection of feces and urine. Indirect calorimetry and $\mathrm{N}$ balance data were analyzed by using regression procedures with SF intake-related variables. Nitrogen excretion shifted from urine to feces with increasing SF intake. This indicates a higher gut entry rate of urea and may explain the improved $\mathrm{N}$ utilization through urea recycling, particularly at $164 \mathrm{~kg}$ of $\mathrm{BW}$. At $108 \mathrm{~kg}$ of $\mathrm{BW}$, the gross efficiency of $\mathrm{N}$ retention was $61 \%$ for calves without SF, and it increased with $\mathrm{SF}$ intake by $5.4 \% / \mathrm{g}$ of DM of SF per day. At $164 \mathrm{~kg}$ of BW, this efficiency was $49 \%$ for calves without SF, and it increased by $9.9 \% / \mathrm{g}$ of $\mathrm{DM}$ of SF per day. The incremental efficiency of energy retention, representing the increase in energy retained per kilojoule of extra

Received February 23, 2012.

Accepted July 17, 2012.

${ }^{1}$ Corresponding author: Harma.Berends@wur.nl digestible energy intake from SF, was $41 \%$ at $108 \mathrm{~kg}$ of BW and $54 \%$ at $164 \mathrm{~kg}$ of BW. Accordingly, the apparent total-tract digestibility of NDF increased with BW, from $46 \%$ at $108 \mathrm{~kg}$ of BW to $56 \%$ at 164 $\mathrm{kg}$ of BW. On average, $5.5 \%$ of gross energy from SF was released as $\mathrm{CH}_{4}$ in veal calves, which is similar to reported values in cattle fed only SF. In conclusion, the provision of low-protein SF resulted in improved $\mathrm{N}$ utilization for protein gain, particularly toward the end of the fattening period. In heavy calves, recycling of urea originating from amino acids in milk replacer potentially contributes substantially to the $\mathrm{N}$ retention of veal calves fed SF.

Key words: digestibility, energy and nitrogen utilization, methane, roughage

\section{INTRODUCTION}

Optimizing solid feed (SF) strategies for veal calves has gained interest since the approval of European guidelines (97/2/EC Directive by the EU Council) on compulsory provision of $\mathrm{SF}$ in addition to the traditional milk replacer diet. Solid feed increasingly represents an important portion of the diet for veal calves, affecting gastrointestinal development, product quality, and nutrient utilization. Although the effects of SF (Vermorel et al., 1980; Ortigues et al., 1990) and milk replacer (Gerrits et al., 1996; Diaz et al., 2001; van den Borne et al., 2006b) on nutrient utilization are well documented, little information is available on the effects of interactions between milk replacer and SF on energy and protein utilization in calves.

Studies available on the effects of SF and milk replacer on nutrient utilization (e.g., Vermorel et al., 1980; Labussière et al., 2009a), have not been designed to measure incremental responses of energy and protein deposition to SF intake. Interactions between milk replacer and SF may affect nutrient utilization. Such potential interactions include urea recycling and leakage of significant (21 to $35 \%$ ) amounts of milk replacer into the rumen (Suárez et al., 2007; Berends et al., 2012). 
In addition, "plaque" (e.g., rumen mucosa containing focal or multifocal patches with coalescing and adhering papillae covered by a sticky mass of feed, hair, and cell debris) formation on the rumen wall is related to the roughage-to-concentrate ratio in the diet (Suárez et al., 2007; Brscic et al., 2011) and could inhibit nutrient uptake from SF. Toward the end of the fattening period, veal calves become less efficient with $\mathrm{N}$ from milk replacer protein (Gerrits et al., 1996), with excessive urea- $\mathrm{N}$ excretion in urine as a result. The reuse of urea$\mathrm{N}$ through recycling by microbes in the gastrointestinal tract is low in calves fed exclusively milk replacer (Gerrits et al., 1999) because of a lack of microbial activity in the rumen. Provision of SF to veal calves could result in increased microbial activity and subsequent incorporation of urea- $\mathrm{N}$ into microbial protein, which may contribute to the $\mathrm{N}$ supply. As reported by Reynolds and Kristensen (2008), urea recycling into the rumen is stimulated by a low protein-to-energy ratio in rumen contents and by high plasma urea concentrations. The latter condition is encountered in veal calves, as illustrated by the low efficiency of utilization of digested proteins from milk replacer (Van den Borne et al., 2006a). To quantify the specific contribution of SF to protein and energy metabolism, responses to incremental quantities of SF should be measured, keeping the milk replacer intake constant.

The aim of this study was to quantify the contribution of a low-protein SF to protein and energy retention in veal calves at 2 stages in the fattening period.

\section{MATERIALS AND METHODS}

This study was conducted at the research facilities of Wageningen University (the Netherlands). Procedures complied with the Dutch Law on Experimental Animals, which complies with ETS123 (Council of Europe 1985 and the 86/609/EEC Directive) and were approved by the Animal Care and Use Committee of Wageningen University.

\section{Animals and Experimental Design}

Forty-eight male Holstein-Friesian calves were used. Calves were raised on a commercial veal farm and were selected based on age, BW, uniformity, and clinical health. Mean age and BW upon arrival were $53 \pm 0.7 \mathrm{~d}$ and $55 \pm 0.3 \mathrm{~kg}$, respectively. Calves arrived in 1 batch at the research facilities, and measurement periods were staggered. Therefore, calves were divided across 4 blocks. Within blocks, calves were assigned randomly to groups of 3 calves ( 4 groups per block). Groups were assigned randomly to 1 of 4 dietary treatments and exposed to their diet for at least 6 wk before the first measurement period. The first measurement period was at $108 \pm 1.1 \mathrm{~kg}$ of BW and lasted $4 \mathrm{~d}$. After the first measurement period, calves were housed in group pens for $7 \mathrm{wk}$. The second measurement period was at $164 \pm$ $1.6 \mathrm{~kg}$ of BW and lasted $4 \mathrm{~d}$.

\section{Housing}

For at least $6 \mathrm{wk}$, groups were housed in pens $(2.35 \times$ $2.45 \mathrm{~m}$ ) equipped with wooden-slatted floors and open fences, and without bedding material. During the last 5 $\mathrm{d}$ before each measurement period, calves were adapted to individual housing on metabolic cages $(0.79 \times 1.85$ $\mathrm{m})$ equipped with wooden-slatted floors and open fences, and without bedding material. Cages enabled audiovisual contact between group mates.

During the measurement periods, each group was housed in 1 of 2 identical $80 \mathrm{~m}^{3}$ indirect calorimetric chambers. Within each chamber, calves were housed individually in metabolic cages. Temperature was maintained at $18^{\circ} \mathrm{C}$, relative humidity at $65 \%$, and air velocity at $<0.2 \mathrm{~m} / \mathrm{s}$. Calves were exposed to light (420 $\mathrm{lx}$ ) from 0545 to $2300 \mathrm{~h}$ and to darkness $(3.5 \mathrm{~lx}$ ) during the remainder of the day.

\section{Diets and Feeding}

Groups were assigned randomly to 1 of 4 incremental levels of SF intake: $0,9,18$, or $27 \mathrm{~g}$ of $\mathrm{DM}$ of $\mathrm{SF} / \mathrm{kg}$ of $\mathrm{BW}^{0.75}$ per day (Table 1), referred to as SF0, SF9, SF18, and SF27, respectively. Provision of SF was adjusted weekly based on the mean BW per group. Dietary treatments were imposed $7 \mathrm{~d}$ after arrival of the calves at the experimental facilities, and the quantity of milk replacer fed was calculated to allow calves to reach a similar BW and growth rate at 2 wk before the start of each of the 2 measurement periods. From $2 \mathrm{wk}$ before the start of the measurement periods onward, milk replacer intake was fixed at $37.3 \mathrm{~g}$ of $\mathrm{DM} / \mathrm{kg}$ of $\mathrm{BW}^{0.75}$ per day at the first measurement period and $40.7 \mathrm{~g}$ of $\mathrm{DM} / \mathrm{kg}$ of $\mathrm{BW}^{0.75}$ per day at the second measurement period, irrespective of SF intake. Ingredient and nutrient composition of the SF components and milk replacer are shown in Table 2. The SF consisted (on a DM basis) of $25 \%$ chopped wheat straw, $25 \%$ corn silage, and $50 \%$ concentrate. The concentrate composition (Table 2) was designed to meet the mineral and vitamin requirements for beef cattle (NRC, 2000).

Milk replacer was reconstituted with water and supplied in a bucket at 40 to $41^{\circ} \mathrm{C}$. Milk replacer concentration was $125 \mathrm{~g} / \mathrm{L}$ during the first measurement period and $143 \mathrm{~g} / \mathrm{L}$ during the second measurement 
Table 1. Experimental treatments for veal calves $(\mathrm{n}=48)$ fed incremental amounts of solid feed (SF; $50 \%$ concentrate, $25 \%$ corn silage, $25 \%$ straw, DM basis) in addition to a milk replacer diet

\begin{tabular}{|c|c|c|c|c|}
\hline \multirow[b]{2}{*}{ Treatment } & \multirow{2}{*}{$\begin{array}{l}\text { No. of } \\
\text { groups }\end{array}$} & \multicolumn{2}{|c|}{$\begin{array}{c}\text { Milk replacer, } \\
\mathrm{g} \text { of } \mathrm{DM} / \mathrm{kg} \text { of } \mathrm{BW}^{0.75} \text { per day }\end{array}$} & \multirow{2}{*}{$\begin{array}{c}\text { Solid feed, } \\
\text { g of DM } / \mathrm{kg} \text { of } \\
\mathrm{BW}^{0.75} \text { per day }\end{array}$} \\
\hline & & $108 \mathrm{~kg}$ of $\mathrm{BW}$ & $164 \mathrm{~kg}$ of BW & \\
\hline SF0 & 4 & 37.3 & 40.7 & 0 \\
\hline SF9 & 4 & 37.3 & 40.7 & 9 \\
\hline SF18 & 4 & 37.3 & 40.7 & 18 \\
\hline SF27 & 4 & 37.3 & 40.7 & 27 \\
\hline
\end{tabular}

${ }^{1}$ Three calves per group.

period. Milk replacer was provided daily in 2 equally sized meals at 0700 and $1600 \mathrm{~h}$, respectively. Calves were allowed 15 min to consume the milk; refusals were weighed twice daily. The SF was supplied directly after each milk meal in the same bucket; refusals were weighed once daily at $0645 \mathrm{~h}$. Calves had free access to water via drinking nipples.

\section{Measurements}

Gas exchange was measured in 9-min intervals by measuring the exchange of $\mathrm{O}_{2}, \mathrm{CO}_{2}$, and $\mathrm{CH}_{4}$, as described by Verstegen and Hoogerbrugge (1987). Each calf was weighed before and after each measurement period. Feces were collected in plastic bags that were attached to the calves. Samples were stored at $-20^{\circ} \mathrm{C}$. Urine was collected in buckets and acidified to $\mathrm{pH} \leq 2$ with $\mathrm{H}_{2} \mathrm{SO}_{4}$ to prevent microbial activity and $\mathrm{NH}_{3}$ volatilization. Aerial $\mathrm{NH}_{3}$ was collected from a quantified sample of the outgoing air in $\mathrm{H}_{2} \mathrm{SO}_{4}$, and $\mathrm{NH}_{4}{ }^{+}$in water that condensed on the heat exchanger was collected quantitatively. Milk replacer and SF components were sampled during each measurement period.

\section{Chemical Analyses}

Samples of milk replacer, concentrate, and straw were pooled by block and BW. Feed components (milk replacer, corn silage, concentrate, straw) were analyzed for DM, ash, N, starch, NDF (except for milk replacer), crude fat, and gross energy content. Fecal samples were pooled by measurement period for each animal and analyzed for DM, ash, N, starch, NDF, crude fat, and gross energy content. Feed refusals were analyzed for $\mathrm{DM}, \mathrm{N}$, and gross energy content. Urine was pooled by measurement period for each animal and analyzed for $\mathrm{N}$ and gross energy content. In addition, $\mathrm{N}$ content was determined in the acid solution containing aerial $\mathrm{NH}_{3}$ and in water that condensed on the heat exchanger.

For determination of DM content, feed refusals, corn silage, and feces were freeze-dried. Feces, feed compo- nents, and feed refusals were ground to pass a 1-mm screen. Dry matter content was determined by drying to a constant weight according to ISO standard 6496 (ISO, 1998b). Crude ash content was determined by incineration in a muffle furnace by combustion at $550^{\circ} \mathrm{C}$ according to ISO standard 5984 (ISO, 2002). Kjeldahl $\mathrm{N}$ content was determined according to ISO standard 5983 (ISO, 1997). Starch content was determined enzymatically as described by Rijnen et al. (2001). Neutral detergent fiber content was analyzed according to the method of Van Soest et al. (1991), with prior amylase treatment, and $\mathrm{Na}_{2} \mathrm{SO}_{3}$ was added to the neutral detergent solution to remove keratinaceous residues of animal origin (hair). Crude fat content was determined after acid hydrolysis according to ISO standard 6492 (ISO, 1999). Gross energy content was analyzed using an adiabatic bomb calorimeter (model C7000 calorimeter; IKA Werke GmbH \& Co. KG, Staufen, Germany) according to ISO standard 9831 (ISO, 1998a). For urine, gross energy content was obtained after freezedrying approximately 8 to $12 \mathrm{~mL}$ in polyethylene bags. All analyses were carried out in duplicate, except for starch content in feces (single) and crude fat content (triplicate).

\section{Calculations}

Intake of gross energy was calculated as feed intake (feed supply minus refusals) multiplied by gross energy content of each feed component. Intake of ME was determined by subtracting energy excretion in feces, urine, and $\mathrm{CH}_{4}$ from gross energy intake. Heat production (HP) was calculated according to the equation of Brouwer (1965) from gas exchange during the last $3 \mathrm{~d}$ of the measurement period. Energy retention was determined by the difference between ME intake and HP. Nitrogen retention was determined as $\mathrm{N}$ intake minus $\mathrm{N}$ losses in feces, urine, aerial $\mathrm{NH}_{3}$, and $\mathrm{NH}_{4}{ }^{+}$in water that condensed on the heat exchanger. Protein retained $(\mathrm{N}$ retention $\times 6.25)$ and energy retained as protein (protein retained $\times 23.7 \mathrm{~kJ} / \mathrm{g}$ ) were determined from $\mathrm{N}$ 
retention. Energy retained as fat was determined by the difference between energy retained and energy retained as protein. The incremental efficiency of energy utilization for growth is expressed as a percentage of extra energy retained $\left(\mathrm{kJ} / \mathrm{kg}\right.$ of $\mathrm{BW}^{0.75}$ per day) per extra gross energy, digestible energy, or ME intake $(\mathrm{kJ} / \mathrm{kg}$ of $\mathrm{BW}^{0.75}$ per day), and was determined by regression of energy retention against gross energy, digestible energy, or ME intake. The incremental efficiency of $\mathrm{N}$ utilization for growth is expressed as a percentage of extra $\mathrm{N}$ retained ( $\mathrm{g}$ of $\mathrm{N} / \mathrm{kg}$ of $\mathrm{BW}^{0.75}$ per day) per extra $\mathrm{N}$ intake ( $\mathrm{g}$ of $\mathrm{N} / \mathrm{kg}$ of $\mathrm{BW}^{0.75}$ per day) and was determined by regression of $\mathrm{N}$ retention against (digested) $\mathrm{N}$ intake. Apparent total-tract digestibility coefficients were determined by regression of the digested nutrient intake against gross nutrient intake.

\section{Statistical Analysis}

The group was the experimental unit, and both the dependent variables and covariables were expressed as averages per group. Dependent variables (i.e., energy and $\mathrm{N}$ balance traits) and apparent total-tract digestibility were analyzed by mixed model analysis (PROC MIXED in SAS 9.20; SAS Institute, 2000), including the fixed effects of block and BW, and SF intake-related variables as covariables, with a random group term to account for repeated observations of the same group. The interaction between SF intake-related variables and BW was included in all models.

Variance-covariance structures were selected based on the Bayesian information criterion. Because the repeated statement consisted of only 2 levels, the variancecovariance structures tested were limited to unstructured and compound symmetry. When model residuals were not normally distributed, data were transformed (log, quadratic, or inverse) to obtain homogeneity of variance. Data are presented as nontransformed means with their SEM. Regression coefficients are presented with their calculated intercepts for the SF0 treatment. Circadian patterns of heat and $\mathrm{CH}_{4}$ production are presented as means per hour with their standard errors of the mean. Differences were considered significant at $P$ $<0.05$. Figures showing circadian patterns of $\mathrm{CH}_{4}$ and heat production are descriptive and are excluded from any statistical analysis.

\section{RESULTS}

In measurement period 1, 4 calves (2 SF0, 2 SF27) were excluded based on exclusion criteria for health or feed refusals. In measurement period 2, 8 calves $(3$ SF0, 2 SF9, 3 SF27) were excluded based on exclusion criteria for health or feed refusals, or because they were excluded in the first measurement period. When a calf was excluded from measurements, a group consisted of 2 instead of 3 calves. Results were not affected by block, unless specified. Realized intakes of milk replacer and SF were similar to targeted intakes as a result of negligible feed refusals. The feeding schedule aimed at similar BW. Average BW was $108 \pm 1.7 \mathrm{~kg}$ in the first measurement period and $164 \pm 2.1 \mathrm{~kg}$ in the second measurement period, and was not affected $(P>0.05)$ by SF level.

\section{Digestibility of SF}

Apparent total-tract digestibility coefficients of SF in the first (108 kg of BW) and second (164 kg of BW) measurement periods are presented in Table 3. Appar-

Table 2. Analyzed nutrient composition of milk replacer and solid feed components

\begin{tabular}{lcccc}
\hline Nutrient $^{1}$ & $\begin{array}{c}\text { Milk } \\
\text { replacer }^{2}\end{array}$ & Concentrate $^{3}$ & $\begin{array}{c}\text { Corn } \\
\text { silage }\end{array}$ & Straw \\
\hline DM, g/kg of product & 968 & 883 & 497 & 923 \\
CP $^{4}$ & 212 & 128 & 77 & 22 \\
Crude fat & 192 & 36 & 28 & 9 \\
Crude ash & 76 & 66 & 36 & 66 \\
Starch & 19 & 450 & 356 & 11 \\
NDF & 7 & 151 & 400 & 814 \\
Gross energy, MJ/kg of DM & 21.7 & 17.7 & 18.7 & 18.0 \\
\hline
\end{tabular}

${ }^{1}$ Expressed in grams per kilogram of DM unless specified otherwise.

${ }^{2}$ Milk replacer composition: $20.0 \%$ whey powder concentrate, $13.3 \%$ delactosed whey, $35.7 \%$ whey powder, $2.0 \%$ starch, $4.0 \%$ wheat protein, $2.5 \%$ soy concentrate, $6.0 \%$ lard, $4.6 \%$ coconut oil, $6.0 \%$ tallow, $2.0 \%$ palm oil, $1.4 \%$ soy lecithin, and $2.5 \%$ premix (provided per kilogram of milk replacer: $3.5 \mathrm{~g}$ of lysine and $2 \mathrm{~g}$ of methionine). ${ }^{3}$ Concentrate composition: $36.1 \%$ barley, $12.5 \%$ carob, $15 \%$ lupines (CP $<335 \mathrm{~g} / \mathrm{kg}$ ), $30 \%$ corn, $1 \%$ premix (lactose carrier, provided per kilogram of concentrate: vitamin A, 4,000 IU; vitamin D, 500 IU; vitamin E, 100 IU; zinc, $25 \mathrm{mg}$; manganese, $20 \mathrm{mg}$; iodine, $0.8 \mathrm{mg}$; selenium, $0.15 \mathrm{mg}$; copper, $15 \mathrm{mg}$; cobalt, $0.1 \mathrm{mg}), 1.15 \%$ $\mathrm{MgSO}_{4} \cdot 7 \mathrm{H}_{2} \mathrm{O}, 0.77 \% \mathrm{NaCl}, 2.15 \% \mathrm{CaCO}_{3}, 1.35 \% \mathrm{KH}_{2} \mathrm{PO}_{4}$.

${ }^{4} \mathrm{~N} \times 6.25$. 
Table 3. Apparent total-tract digestibility coefficients of solid feed in veal calves at 108 and $164 \mathrm{~kg}$ of BW

\begin{tabular}{|c|c|c|c|}
\hline \multirow[b]{2}{*}{ Item } & \multicolumn{2}{|c|}{$\begin{array}{l}\text { Apparent total-tract } \\
\text { digestibility coefficient }\end{array}$} & \multirow{2}{*}{$\begin{array}{l}\text { Effect } \\
\text { of BW }\end{array}$} \\
\hline & $108 \mathrm{~kg}$ of $\mathrm{BW}$ & $164 \mathrm{~kg}$ of BW & \\
\hline DM & $0.62 \pm 0.022$ & $0.66 \pm 0.013$ & NS \\
\hline Protein ${ }^{3}$ & $0.35 \pm 0.057$ & $0.39 \pm 0.059$ & NS \\
\hline Ash & $0.51 \pm 0.035$ & $0.51 \pm 0.028$ & NS \\
\hline Fat $^{4}$ & $0.55 \pm 0.113$ & $0.54 \pm 0.077$ & NS \\
\hline Energy & $0.58 \pm 0.028$ & $0.62 \pm 0.016$ & NS \\
\hline Starch $^{5}$ & $0.97 \pm 0.004$ & $0.98 \pm 0.004$ & NS \\
\hline NDF & $0.46 \pm 0.027$ & $0.56 \pm 0.025$ & $* *$ \\
\hline
\end{tabular}

${ }^{1}$ Calculated by regression coefficient $\beta,(y=a+\beta \cdot x)$, representing the change in apparent total-tract digested intake per increase in gross intake, where intercept a represents the digested nutrient intake at SF0 (calves fed no solid feed).

${ }^{2}$ The $P$-value represents the effect of BW (i.e., measurement period) on the apparent total-tract digestibility coefficient.

${ }^{3}$ Data were transformed (quadratic) to obtain homogeneity of variance.

${ }^{4}$ The effect of block was significant $(P<0.05)$.

${ }^{5}$ Data were transformed (inverse) to obtain homogeneity of variance.

** $P<0.01$.

ent total-tract digestibility coefficients of DM, crude ash, crude fat, gross energy, and NDF from SF were in the range of 46 to $66 \%$. The apparent total-tract digestibility values of CP from SF averaged $35 \%$ at 108 $\mathrm{kg}$ of $\mathrm{BW}$ and $39 \%$ at $164 \mathrm{~kg}$ of BW. The apparent total-tract digestibility of starch from SF exceeded $97 \%$ at 108 and $164 \mathrm{~kg}$ of BW. The apparent total-tract digestibility of NDF from SF was greater $(P<0.01)$ at $164 \mathrm{~kg}$ of $\mathrm{BW}(56 \%)$ than at $108 \mathrm{~kg}$ of $\mathrm{BW}(46 \%)$.

\section{N Balance}

Nitrogen intake increased with increasing SF intake, from 1.26 to $1.65 \mathrm{~g}$ of $\mathrm{N} / \mathrm{kg}$ of $\mathrm{BW}^{0.75}$ per day at 108 $\mathrm{kg}$ of $\mathrm{BW}$ and from 1.38 to $1.76 \mathrm{~g}$ of $\mathrm{N} / \mathrm{kg}$ of $\mathrm{BW}^{0.75}$ per day at $164 \mathrm{~kg}$ of BW (Table 4). The incremental efficiency with which ingested $\mathrm{N}$ was retained tended to increase $(P<0.10)$ from $43 \%$ at $108 \mathrm{~kg}$ of BW to $77 \%$ at $164 \mathrm{~kg}$ of $\mathrm{BW}$ (Table 5 ; estimates for $\beta$ ). The incremental efficiency with which digested $\mathrm{N}$ was retained exceeded $100 \%$, and it increased $(P<0.05)$ from $124 \%$ at $108 \mathrm{~kg}$ of BW to $187 \%$ at $164 \mathrm{~kg}$ of BW (Table 5; estimates for $\beta$ ). Fecal $\mathrm{N}$ excretion increased with $\mathrm{N}$ intake from SF $(P<0.001)$ and was unaffected by BW. Urinary $\mathrm{N}$ excretion did not change with increasing $\mathrm{N}$ intake at $108 \mathrm{~kg}$ of $\mathrm{BW}$, but it did decrease with increasing $\mathrm{N}$ intake at $164 \mathrm{~kg}$ of $\mathrm{BW}(P<0.001)$. The efficiency of $\mathrm{N}$ retention, expressed as a percentage of $\mathrm{N}$ intake, increased with increasing $\mathrm{N}$ intake from $\mathrm{SF}$ $(P<0.05$; Table 5$)$.

\section{Energy Balance}

The effects of SF intake on $\mathrm{N}$ and energy balance parameters at 108 and $164 \mathrm{~kg}$ of $\mathrm{BW}$ are shown in Table 5. Table 4 includes descriptive energy and $\mathrm{N}$ balance data for each treatment separately. The incremental efficiency with which digestible energy from SF was retained was $41 \%$ at $108 \mathrm{~kg}$ of BW and $54 \%$ at $164 \mathrm{~kg}$ of BW (Table 5; estimates for $\beta$ ). Calves in the SF0 group retained $106 \mathrm{~kJ} / \mathrm{kg}$ of $\mathrm{BW}^{0.75}$ per day of energy as protein at a digestible energy intake of $770 \mathrm{~kJ} / \mathrm{kg}$ of $\mathrm{BW}^{0.75}$ per day at $108 \mathrm{~kg}$ of $\mathrm{BW}$, and $97 \mathrm{~kJ} / \mathrm{kg}$ of $\mathrm{BW}^{0.75}$ per day of energy as protein at a digestible energy intake of $845 \mathrm{~kJ} / \mathrm{kg}$ of $\mathrm{BW}^{0.75}$ per day at $164 \mathrm{~kg}$ of BW (Table 4; SF0 level). Protein retention increased ( $P$ $<0.001)$ with increasing digestible energy intake from SF, with incremental efficiencies of $9 \%$ at $108 \mathrm{~kg}$ of BW and $14 \%$ at $164 \mathrm{~kg}$ of BW. Fat retention increased $(P<$ 0.001 ) with increasing digestible energy intake from $\mathrm{SF}$, with incremental efficiencies of $33 \%(108 \mathrm{~kg}$ of BW) and $40 \%$ (164 kg of BW).

The influence of SF intake on the circadian patterns of HP is shown in Figure 1. Differences between treatments (i.e., greater HP with increasing SF intake) seemed more pronounced during the postprandial period than during the preprandial period at $108 \mathrm{~kg}$ of BW. At $164 \mathrm{~kg}$ of BW, treatment differences were more constant during the day. The proportion of ME intake spent on HP decreased $(P<0.05)$ with BW (Table 5$)$. Methane production was 1.2 and $1.6 \mathrm{~kJ} / \mathrm{kg}$ of $\mathrm{BW}^{-0.75}$ per day in SF0 calves at 108 and $164 \mathrm{~kg}$ of BW, respectively. Methane production increased $(0.09 \mathrm{~kJ}$ of $\mathrm{CH}_{4} / \mathrm{kJ}$ of digestible energy; $P<0.001$ ) with increasing digestible energy from SF. The influence of SF intake on the circadian pattern of $\mathrm{CH}_{4}$ production is shown in Figure 2 for 108 and $164 \mathrm{~kg}$ of BW. Effects of SF intake were more pronounced during the early postprandial period at $108 \mathrm{~kg}$ of $\mathrm{BW}$ than at $164 \mathrm{~kg}$ of $\mathrm{BW}$.

\section{DISCUSSION}

\section{Digestibility and $\mathrm{CH}_{4}$}

Apparent total-tract digestibility coefficients for SF0 calves were in the range of 91 to $99 \%$ for DM, N, crude fat, gross energy, and starch (results not shown) and are in close accordance with values for calves fed exclusively milk from 65 to $200 \mathrm{~kg}$ of BW (Gerrits et al., 1996; Diaz et al., 2001; van den Borne et al., 2006b). Apparent total-tract digestibility coefficients of DM (64\%) and gross energy (60\%) from SF in our calves were in close agreement with those in heifer calves $(67 \%$; Ortigues et al., 1990) fed SF with a similar composition 
Table 4. Nitrogen and energy balances (mean \pm SEM) in veal calves fed incremental amounts of solid feed (SF) in addition to a milk replacer (MR) diet at 108 and $164 \mathrm{~kg}$ of BW ${ }^{1}$

\begin{tabular}{|c|c|c|c|c|c|c|c|c|}
\hline \multirow[b]{2}{*}{ Treatment $^{2}$} & \multicolumn{4}{|c|}{$108 \mathrm{~kg}$ of $\mathrm{BW}$} & \multicolumn{4}{|c|}{$164 \mathrm{~kg}$ of BW } \\
\hline & SF0 & SF9 & SF18 & $\mathrm{SF} 27$ & SF0 & SF9 & SF18 & $\mathrm{SF} 27$ \\
\hline $\begin{array}{l}\text { No. of groups, no. } \\
\text { of animals }\end{array}$ & 4,10 & 4,12 & 4,12 & 4,10 & 4,9 & 4,10 & 4,12 & 4,9 \\
\hline $\begin{array}{l}\text { Metabolic BW, } \\
\mathrm{kg}^{0.75} / \text { animal }\end{array}$ & $33.3 \pm 0.82$ & $33.4 \pm 0.29$ & $33.1 \pm 0.62$ & $34.0 \pm 1.28$ & $45.4 \pm 0.99$ & $46.2 \pm 0.26$ & $45.4 \pm 0.34$ & $46.4 \pm 1.55$ \\
\hline \multicolumn{9}{|c|}{$\mathrm{N}$ balance, $\mathrm{g}$ of $\mathrm{N} / \mathrm{kg}$ of $\mathrm{BW}^{0.75}$ per day } \\
\hline Total $\mathrm{N}$ intake & $1.26 \pm 0.004$ & $1.39 \pm 0.005$ & $1.53 \pm 0.005$ & $1.65 \pm 0.006$ & $1.38 \pm 0.005$ & $1.51 \pm 0.007$ & $1.64 \pm 0.006$ & $1.76 \pm 0.021$ \\
\hline $\mathrm{N}$ from $\mathrm{MR}$ & $1.26 \pm 0.004$ & $1.26 \pm 0.006$ & $1.26 \pm 0.003$ & $1.26 \pm 0.002$ & $1.38 \pm 0.005$ & $1.37 \pm 0.006$ & $1.37 \pm 0.007$ & $1.37 \pm 0.006$ \\
\hline $\mathrm{N}$ from $\mathrm{SF}$ & $0 \pm-$ & $0.13 \pm 0.001$ & $0.26 \pm 0.002$ & $0.39 \pm 0.004$ & $0 \pm-$ & $0.14 \pm 0.001$ & $0.27 \pm 0.003$ & $0.39 \pm 0.017$ \\
\hline Fecal N & $0.09 \pm 0.006$ & $0.20 \pm 0.014$ & $0.31 \pm 0.024$ & $0.34 \pm 0.023$ & $0.10 \pm 0.007$ & $0.18 \pm 0.001$ & $0.25 \pm 0.010$ & $0.33 \pm 0.020$ \\
\hline Digestible $\mathrm{N}$ intake & $1.17 \pm 0.009$ & $1.20 \pm 0.013$ & $1.21 \pm 0.027$ & $1.32 \pm 0.022$ & $1.28 \pm 0.003$ & $1.33 \pm 0.007$ & $1.39 \pm 0.013$ & $1.42 \pm 0.019$ \\
\hline Urinary N & $0.43 \pm 0.038$ & $0.45 \pm 0.031$ & $0.44 \pm 0.019$ & $0.40 \pm 0.002$ & $0.64 \pm 0.021$ & $0.58 \pm 0.023$ & $0.55 \pm 0.023$ & $0.50 \pm 0.026$ \\
\hline $\mathrm{N}$ retention & $0.73 \pm 0.04$ & $0.73 \pm 0.041$ & $0.76 \pm 0.010$ & $0.91 \pm 0.026$ & $0.62 \pm 0.02$ & $0.73 \pm 0.029$ & $0.82 \pm 0.035$ & $0.91 \pm 0.037$ \\
\hline \multicolumn{9}{|c|}{ Energy balance, $\mathrm{kJ} / \mathrm{kg}$ of $\mathrm{BW}^{0.75}$ per day } \\
\hline Total GE intake & $804 \pm 2.4$ & $973 \pm 2.9$ & $1,144 \pm 2.1$ & $1,305 \pm 3.0$ & $881 \pm 5.1$ & $1,054 \pm 4.3$ & $1,218 \pm 8.5$ & $1,373 \pm 26.6$ \\
\hline GE from MR & $804 \pm 2.4$ & $802 \pm 3.2$ & $806 \pm 0.6$ & $803 \pm 1.0$ & $881 \pm 5.1$ & $877 \pm 3.4$ & $876 \pm 4.4$ & $874 \pm 3.9$ \\
\hline GE from SF & $0 \pm-$ & $171 \pm 0.6$ & $339 \pm 2.4$ & $502 \pm 2.6$ & $0 \pm-$ & $176 \pm 1.7$ & $342 \pm 7.4$ & $500 \pm 26.9$ \\
\hline Fecal energy & $34 \pm 4.8$ & $95 \pm 7.1$ & $191 \pm 13.3$ & $234 \pm 11.5$ & $36 \pm 2.4$ & $94 \pm 1.2$ & $147 \pm 4.1$ & $225 \pm 11.9$ \\
\hline DE intake & $770 \pm 5.8$ & $878 \pm 5.8$ & $954 \pm 14.3$ & $1,072 \pm 9.0$ & $845 \pm 7.2$ & $960 \pm 5.2$ & $1,070 \pm 12.3$ & $1,148 \pm 15.5$ \\
\hline $\mathrm{CH}_{4}$ & $1.2 \pm 0.49$ & $11.7 \pm 1.65$ & $19.7 \pm 0.84$ & $28.9 \pm 3.34$ & $1.6 \pm 0.38$ & $15.4 \pm 1.03$ & $22.9 \pm 1.51$ & $29.8 \pm 2.63$ \\
\hline Urinary energy & $20 \pm 2.1$ & $26 \pm 1.3$ & $30 \pm 1.5$ & $28 \pm 1.2$ & $31 \pm 1.3$ & $34 \pm 2.3$ & $37 \pm 4.7$ & $41 \pm 4.1$ \\
\hline ME intake & $749 \pm 4.8$ & $839 \pm 5.8$ & $904 \pm 14.4$ & $1015 \pm 9.9$ & $812 \pm 7.4$ & $911 \pm 7.1$ & $1,011 \pm 9.7$ & $1,075 \pm 21.0$ \\
\hline Heat production & $577 \pm 17.2$ & $603 \pm 3.1$ & $660 \pm 2.1$ & $721 \pm 14.5$ & $576 \pm 17.4$ & $616 \pm 5.6$ & $655 \pm 13.6$ & $682 \pm 10.6$ \\
\hline Energy retention & $172 \pm 20.0$ & $236 \pm 6.6$ & $244 \pm 13.4$ & $294 \pm 20.1$ & $236 \pm 21.6$ & $295 \pm 3.7$ & $356 \pm 15.4$ & $393 \pm 18.6$ \\
\hline As protein & $108 \pm 5.9$ & $108 \pm 6.0$ & $112 \pm 1.4$ & $135 \pm 3.9$ & $92 \pm 2.9$ & $108 \pm 4.3$ & $122 \pm 5.2$ & $134 \pm 5.5$ \\
\hline As fat & $64 \pm 19.4$ & $128 \pm 6.2$ & $132 \pm 13.1$ & $159 \pm 18.2$ & $144 \pm 20$ & $186 \pm 3.4$ & $234 \pm 11.9$ & $259 \pm 16.1$ \\
\hline
\end{tabular}

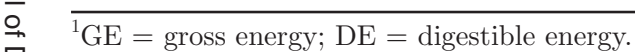

兰. ${ }^{2}$ Treatments correspond to SF intake levels: 0 (SF0), 9 (SF9), 18 (SF18), or 27 (SF27) g of DM/kg of BW ${ }^{0.75}$ per day. The SF (50\% concentrate, $25 \%$ straw, $25 \%$ corn silage; DM basis) was fed in addition to an MR diet. 
Table 5. Effects of incremental solid feed (SF) intake, fed in addition to a milk replacer (MR) diet, on $\mathrm{N}$ and energy balance parameters in veal calves at 108 and $164 \mathrm{~kg}$ of $\mathrm{BW}^{1}$

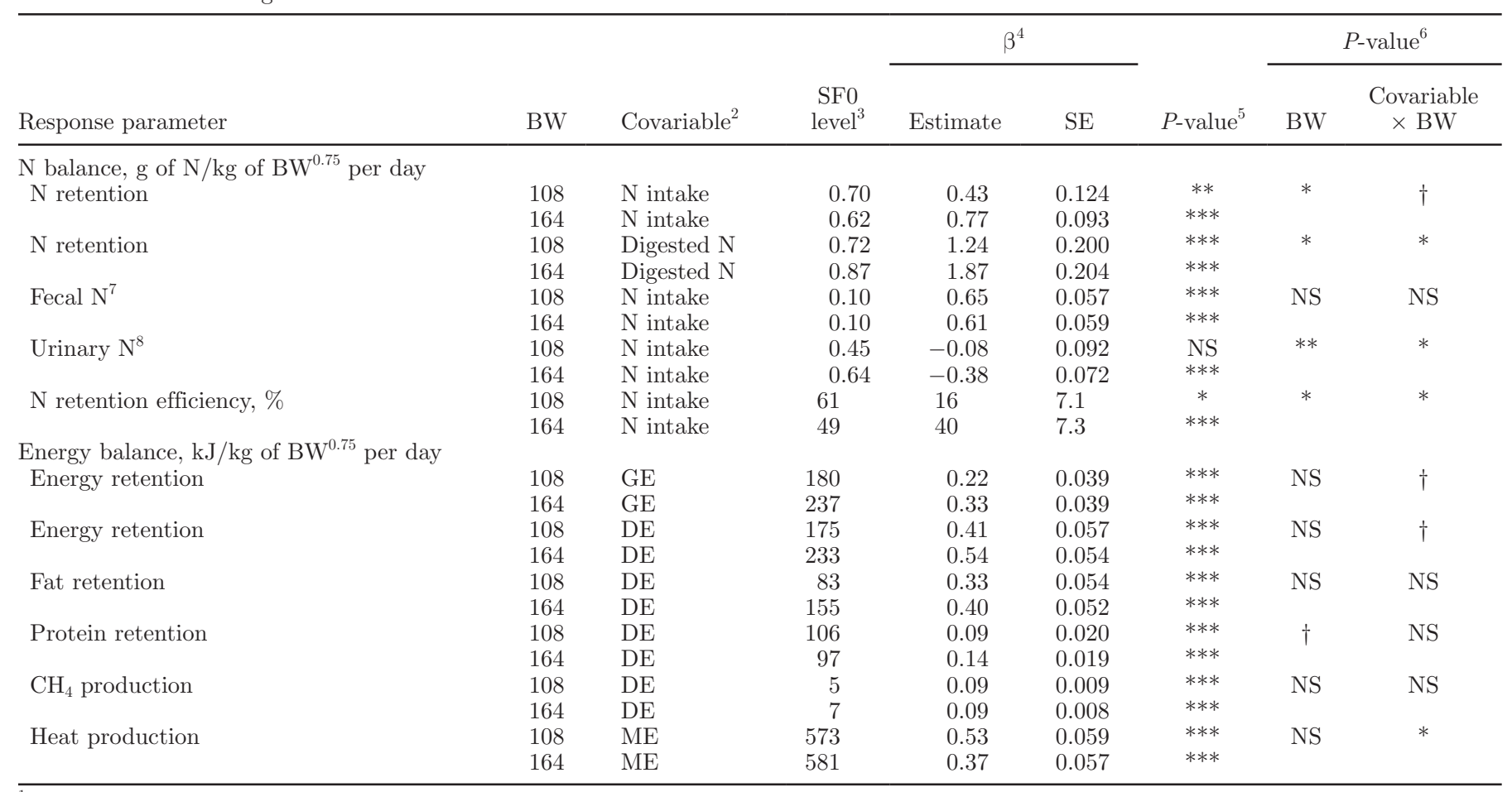

${ }^{1} \mathrm{GE}=$ gross energy; $\mathrm{DE}=$ digestible energy.

${ }^{2}$ Covariable represents the $\mathrm{N}$ intake, digested $\mathrm{N}$ intake, GE, or DE.

${ }^{3}$ The SF0 level (in $\mathrm{kJ}$ or $\mathrm{g}$ of $\mathrm{N} / \mathrm{kg}$ of $\mathrm{BW}^{0.75}$ per day or \%) represents an estimate of the response parameter in calves fed no SF.

${ }^{4}$ Regression coefficient $\beta$, dimensionless $(\mathrm{y}=\mathrm{a}+\beta \cdot \mathrm{x}$ ), represents the change in the response parameter per increase in the covariable; it represents the incremental efficiency of utilization of energy or $\mathrm{N}$ from SF. The intercept a represents the digested nutrient intake at SF0 (calves fed no solid feed).

${ }^{5}$ Probability for the test if the regression coefficient $(\beta)$ equals 0 . The effect of block was not significant and was therefore excluded from the model.

${ }^{6}$ The $P$-value for BW represents the statistical significance of the effect of BW on the response parameter; the $P$-value for covariable $\times$ BW represents the significance of the interaction between the covariable and the main effect of BW. The interpretation of a significant interaction between the covariable and BW is that the regression coefficient differs between levels of BW.

${ }^{7}$ Data were transformed $(\log )$ to obtain homogeneity of variance.

${ }^{8}$ Data were transformed (quadratic) to obtain homogeneity of variance.

$\dagger P<0.10 ;{ }^{*} P<0.05 ;{ }^{* *} P<0.01 ;{ }^{* * *} P<0.001$.

(roughage-to-concentrate ratio of 55:45 and CP content of $10.5 \%$ ) as the SF provided to our calves. However, apparent total-tract digestibility of $\mathrm{CP}$ was lower in our study $(37 \%)$ compared with the study by Ortigues et al. (1990), who found a CP digestibility of $45 \%$. Apparent total-tract digestibility of NDF increased from $46 \%$ at $108 \mathrm{~kg}$ of BW to $56 \%$ at $164 \mathrm{~kg}$ of BW. This suggests that rumen or hindgut fermentation, or both, are further optimized with time, although rumen development is assumed to require less than 7 or $8 \mathrm{wk}$ of SF exposure (Zitnan, 1998; Suárez et al., 2006). This increase could also point to a decreased rumen passage rate at $108 \mathrm{~kg}$ of $\mathrm{BW}$ relative to $164 \mathrm{~kg}$ of $\mathrm{BW}$.

The digestibility coefficients of SF are calculated as the incremental response of digested nutrient intake to nutrient intake; therefore, it is assumed that the diges- tion of nutrients from milk replacer is not affected by SF intake. Although passage rate may be decreased by SF intake, the increase in apparent digestibility of milk replacer associated with this decrease is expected to be small because of a generally high level of DM digestibility (94 to 96\%; van den Borne et al., 2006b; Labussière et al., 2009b).

Methane production from calves in the SF0 group was negligible, as shown previously in calves fed milk (van den Borne et al., 2006b; Labussière et al., 2009a). Methane production increased with SF intake and with BW from $5.4 \%$ of gross energy from SF at $108 \mathrm{~kg}$ to $5.5 \%$ of gross energy from SF at $164 \mathrm{~kg}$ of BW. These values are close to the range of 6.0 to $6.6 \%$ of gross energy reported for adult dairy cows (Mills et al., 2001). In veal calves, SF supplementation with very high 

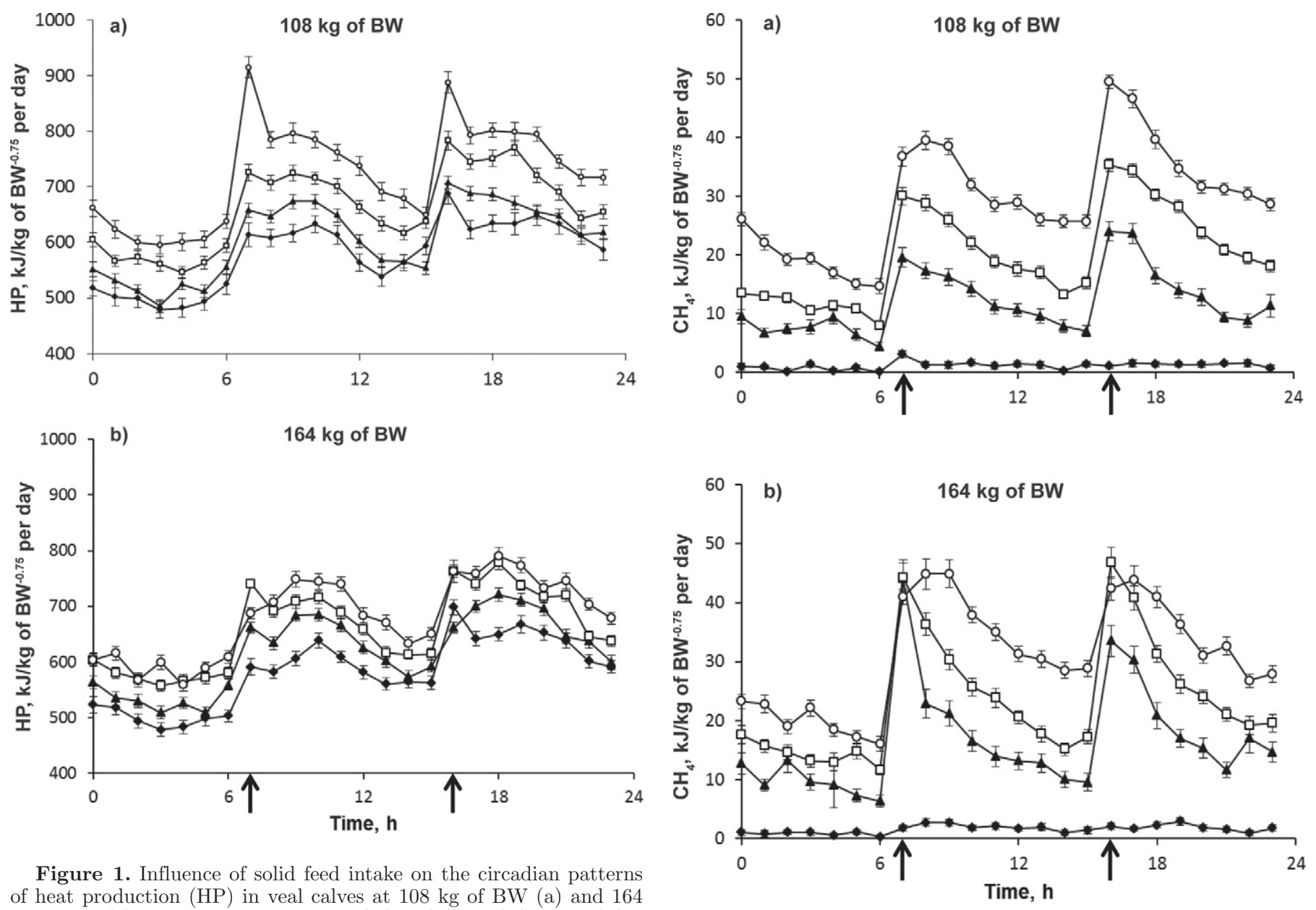

Figure 1. Influence of solid feed intake on the circadian pattern of heat production (HP) in veal calves at $108 \mathrm{~kg}$ of BW (a) and 164 $\mathrm{kg}$ of BW (b). Solid feed intake was $0(\diamond), 9(\mathbf{\Delta}), 18(\square)$, or $27(\bigcirc) \mathrm{g}$ of $\mathrm{DM} / \mathrm{kg}$ of $\mathrm{BW}^{0.75}$ per day. Solid feed $(50 \%$ concentrate, $25 \%$ straw, $25 \%$ corn silage; DM basis) was fed in addition to a milk replacer diet. Results are expressed as means \pm SEM; $\mathrm{n}=4$ for each treatment. Arrows represent feeding times.

(>90\%) levels of concentrates resulted in $\mathrm{CH}_{4}$ yields ranging from 3.2 to $9.1 \%$ of gross energy from SF (Labussière et al., 2009a). The latter values are remarkably high because it has been demonstrated in beef cattle that high-concentrate diets typically produce $\mathrm{CH}_{4}$ at levels between 2 and $3 \%$ of gross energy (Johnson and Johnson, 1995). It is possible that ruminal drinking (i.e., leakage of milk replacer to the rumen) contributed to enhanced $\mathrm{CH}_{4}$ production because of anaerobic fermentation of milk replacer (see van den Borne et al., 2004). Observations of ruminal drinking in future studies on $\mathrm{CH}_{4}$ production in veal calves would be needed to further substantiate this idea. In the present study, the apparent total-tract digestibility of NDF increased by $10 \%$ when BW increased from 108 to $164 \mathrm{~kg}$, and this increase was partly accompanied by an increase in proportional $\mathrm{CH}_{4}$ loss, from 5.4 to $5.5 \%$ of gross energy from SF.

Figure 2. Influence of solid feed intake on the circadian patterns of $\mathrm{CH}_{4}$ production in veal calves at $108 \mathrm{~kg}$ of BW (a) and $164 \mathrm{~kg}$ of BW (b). Solid feed intake was $0(\checkmark), 9(\boldsymbol{\Lambda}), 18(\square)$, or $27(\bigcirc) \mathrm{g}$ of $\mathrm{DM} / \mathrm{kg}$ of $\mathrm{BW}^{0.75}$ per day. Solid feed (50\% concentrate, $25 \%$ straw, $25 \%$ corn silage; DM basis) was fed in addition to a milk replacer diet. Results are expressed as means \pm SEM; $\mathrm{n}=4$ for each treatment. Arrows represent feeding times.

The circadian pattern of $\mathrm{CH}_{4}$ production shown in Figure 2 can be explained by the positive relationship between DMI and $\mathrm{CH}_{4}$ production (Dijkstra et al., 2011). Time between feeding (indicated with arrows) and the maximum rate of $\mathrm{CH}_{4}$ production of SF27 were within the range of 47 to $141 \mathrm{~min}$ reported by Crompton et al. (2011) for dairy cows, although calves in the SF9 and SF18 groups reached their maximum rate of $\mathrm{CH}_{4}$ production earlier than $47 \mathrm{~min}$.

\section{N Utilization}

For calves in the SF0 group, the gross efficiency of $\mathrm{N}$ retention $(61 \pm 3.0 \%$ at $108 \mathrm{~kg}$ of $\mathrm{BW}$ and $49 \pm$ $1.6 \%$ at $164 \mathrm{~kg}$ of $\mathrm{BW}$ ) is well in line with measurements performed on calves exclusively on milk replacer 
(van den Borne et al., 2006b; Labussière et al., 2009b), decreasing with age or BW (Gerrits et al., 1996; Labussière et al., 2009b). The gross efficiency of $\mathrm{N}$ retention increased with SF intake, with $5.4 \% / \mathrm{g}$ of DM of SF per day at $108 \mathrm{~kg}$ of $\mathrm{BW}$ and with $9.9 \% / \mathrm{g}$ of $\mathrm{DM}$ of $\mathrm{SF}$ per day at $164 \mathrm{~kg}$ of $\mathrm{BW}$. When expressed per gram of $\mathrm{N}$ intake, the increase in gross efficiency of $\mathrm{N}$ retention was $0.5 \% / \mathrm{g}$ of $\mathrm{N}$ from $\mathrm{SF}$ per day at $108 \mathrm{~kg}$ of $\mathrm{BW}$ and $0.9 \% / \mathrm{g}$ of $\mathrm{N}$ from SF per day at $164 \mathrm{~kg}$ of BW. The incremental efficiency with which total protein and all essential amino acids are used for growth is typically low (30 to 40\%) in calves exclusively fed milk replacer (Gerrits et al., 1996, 1998). In our study, the incremental efficiency of $\mathrm{N}$ utilization from $\mathrm{SF}$ was substantially greater (43 and $77 \%$ at 108 and $164 \mathrm{~kg}$ of $\mathrm{BW}$, respectively), which is remarkable, especially when considering the poor $\mathrm{N}$ digestibility of the $\mathrm{SF}$ sources used (92 to $95 \%$ for milk replacer vs. $55 \%$ for SF, respectively; van den Borne et al., 2006b; CVB, 2007; Labussière et al., 2009a). It is hypothesized that the high incremental efficiency of $\mathrm{N}$ utilization in our calves is caused by recycling of urea-N. In this way, urea-N can increase the microbial protein supply to the animal, which can subsequently be used for protein synthesis. This corresponds with the observed shift in $\mathrm{N}$ excretion from urine to feces, particularly at $164 \mathrm{~kg}$ of BW, leading to low estimates of apparent $\mathrm{N}$ digestibility of SF (35 to 39\%) when compared with studies in heifers (45\%; Ortigues et al., 1990). Moreover, it explains the observation that the incremental $\mathrm{N}$ retained exceeded the incremental apparently digested $\mathrm{N}$ from SF (0.43 vs. 0.35 at $108 \mathrm{~kg}$ of BW and 0.77 vs. 0.39 at $164 \mathrm{~kg}$ of BW). These data indicate that urea recycling contributes to at least $19 \%$ of the extra $\mathrm{N}$ retention at $108 \mathrm{~kg}$ of BW (difference between incremental N retained and the incremental apparently digested $\mathrm{N}$ from $\mathrm{SF}$, as a percentage of incremental $\mathrm{N}$ retained) and to at least $49 \%$ at $164 \mathrm{~kg}$ of BW. This substantial urea recycling may be particularly stimulated by the low protein content of the SF. It has been demonstrated that urea recycling is stimulated by a low protein-toenergy ratio in rumen contents, but also by high blood urea concentrations (Reynolds and Kristensen, 2008).

In contrast to our findings, Labussière et al. (2009a) found that the provision of SF in addition to milk replacer was associated with a reduced efficiency of $\mathrm{N}$ retention in calves. Several explanations are conceivable for the differences between their study and the present experiment. First, to stimulate urea recycling, the $\mathrm{CP}$ content in the SF was deliberately reduced to $88 \mathrm{~g}$ of $\mathrm{CP} / \mathrm{kg}$ of $\mathrm{DM}$ compared with approximately $163 \mathrm{~g}$ of $\mathrm{CP} / \mathrm{kg}$ of $\mathrm{DM}$ in the diets of Labussière et al. (2009a). The incorporation of blood urea-N into microbial protein through urea recycling is inversely related to the level of protein intake in heifer calves (Bunting et al., 1989; Marini and Van Amburgh, 2003). Therefore, the reduced CP in our experiment compared with that in the study by Labussière et al. (2009a) could have increased urea recycling and contributed to the greater incremental efficiency of $\mathrm{N}$ retention. Second, high concentrate proportions $(>70 \%)$ in $\mathrm{SF}$ provided to veal calves next to milk replacer have been shown to lead to poor rumen development and plaque formation on the rumen wall (Suárez et al., 2006, 2007; Brscic et al., 2011). When SF consists of only concentrates, plaque is present in almost all calves (Suárez et al., 2006 , 2007). Plaque formation might inhibit not only nutrient uptake by the rumen wall, but also urea- $\mathrm{N}$ entry into the rumen. The proportion of concentrate in the SF mixture fed by Labussière et al. (2009a) exceeded $90 \%$, whereas our SF consisted of $50 \%$ concentrate. Therefore, plaque formation may have inhibited nutrient transport through the rumen wall in the study by Labussière et al. (2009a).

The effects of SF intake on $\mathrm{N}$ efficiency are more pronounced at $164 \mathrm{~kg}$ of $\mathrm{BW}$ than at $108 \mathrm{~kg}$ of BW. The greater incremental $\mathrm{N}$ efficiency at $164 \mathrm{~kg}$ of BW could be explained by the lower efficiency ( 45 vs. $58 \%$ ) with which dietary $\mathrm{N}$ was retained for calves in the SF0 group at $164 \mathrm{~kg}$ compared with those at $108 \mathrm{~kg}$ of BW. This corresponds with the general decrease in efficiency of $\mathrm{N}$ utilization with age in calves fed exclusively on milk replacer (Gerrits et al., 1996; van den Borne et al., 2006a,b) and allows more room for improving $\mathrm{N}$ utilization in heavier calves. In addition, the observed increase in NDF digestibility with BW indicates improved fermentation and therefore a greater demand for urea- $\mathrm{N}$ for microbial protein synthesis.

\section{Energy Utilization}

The incremental efficiency of energy retention (energy retained per kilojoule of digestible energy from $\mathrm{SF})$ was $41 \%$ at $108 \mathrm{~kg}$ of BW and increased to $54 \%$ at $164 \mathrm{~kg}$ of BW. When expressed per kilojoule of ME, the incremental efficiency of energy retention was $47 \%$ at $108 \mathrm{~kg}$ of BW and $63 \%$ at $164 \mathrm{~kg}$ of BW. The efficiency of energy retention at $164 \mathrm{~kg}$ of $\mathrm{BW}$ was greater than that in weaned calves at $200(49 \%)$ and $286(55 \%) \mathrm{kg}$ of BW fed SF ad libitum (Vermorel et al., 1980). In addition, the incremental efficiency of energy retention calculated from the data of Ortigues et al. (1990) was $41 \%$ in calves of similar BW $(161 \mathrm{~kg})$ fed exclusively $\mathrm{SF}$ of a similar composition (roughage-to-concentrate ratio of 55:45 and CP content of $10.5 \%$ ) as provided to our calves.

As discussed by Labussière et al. (2009a, 2011), any increase in ME intake (from SF or milk replacer) 
would typically increase fasting HP, likely related to an increased contribution of metabolically very active tissues. For the range in ME intake from SF in our experiment, the fasting HP could be increased by $0.1 \mathrm{~kJ} /$ $\mathrm{kJ}$ of SF per kilogram of $\mathrm{BW}^{0.75}$ per day. This increase, however, is already accounted for in the energetic efficiencies described above. It would imply, however, that the extra energy retained with more SF intake is not completely reflected in increased carcass weights. Increasing the intake of SF may increase weights of the gastrointestinal tissues, such as the rumen (Berends et al., 2012). Current data showed an increase in energetic efficiency from SF with BW. Apart from the more efficient utilization of protein for growth, this increase in efficiency reflects preferential fat retention with increasing age or BW (Gerrits et al., 1996).

\section{CONCLUSIONS}

The provision of low-protein SF enhanced $\mathrm{N}$ utilization for protein gain in veal calves, particularly toward the end of the fattening period. At $108 \mathrm{~kg}$ of BW, the gross efficiency of $\mathrm{N}$ retention was $61 \%$ for calves without SF, and it increased with SF intake by $5.4 \% / \mathrm{g}$ of DM of SF per day. At $164 \mathrm{~kg}$ of BW, this efficiency was $49 \%$ for calves without SF, and it increased by $9.9 \% / \mathrm{g}$ of DM of SF per day. Recycling of urea (mainly originating from milk amino acids) potentially contributed substantially to incremental $\mathrm{N}$ retention in heavy veal calves when SF was fed. The incremental efficiency of energy retention, representing the increase in energy retained per kilojoule of extra digestible energy intake from SF, was greater at $164 \mathrm{~kg}$ of BW (54\%) than at $108 \mathrm{~kg}$ of BW (41\%). Similarly, the apparent total-tract digestibility of NDF increased with BW, from $46 \%$ at $108 \mathrm{~kg}$ of BW to $56 \%$ at $164 \mathrm{~kg}$ of BW, which may also have increased the demand for urea- $\mathrm{N}$ for microbial protein synthesis and thus stimulated urea recycling. Methane production from SF in veal calves was similar to reported values in cattle fed only SF.

\section{ACKNOWLEDGMENTS}

The authors thank Carène Bulte, Maike Pegge, Sabrina Podesta, Janneke Snijders, Laura Webb, Tamme Zandstra, and the personnel of the De Haar research facilities for their technical assistance. Financial support of the Netherlands Organization for Scientific Research (The Hague, the Netherlands) and the Product Board Animal Feed (The Hague, the Netherlands) is gratefully acknowledged.

\section{REFERENCES}

Berends, H., C. G. Van Reenen, N. Stockhofe, and W. J. J. Gerrits. 2012. Effects of early rumen development and SF composition on growth performance and abomasal health in veal calves. J. Dairy Sci. 95:3190-3199.

Brouwer, E. 1965. Report of sub-committee on constants and factors. Pages 441-443 in Energy Metabolism. K. L. Blaxter, ed. Academic Press, London, UK.

Brscic, M., L. F. M. Heutinck, M. Wolthuis-Fillerup, N. Stockhofe, B. Engel, E. K. Visser, F. Gottardo, E. A. M. Bokkers, B. J. Lensink, G. Cozzi, and C. G. van Reenen. 2011. Prevalence of gastrointestinal disorders recorded at postmortem inspection in white veal calves and associated risk factors. J. Dairy Sci. 94:853-863.

Bunting, L. D., J. A. Boling, and C. T. MacKown. 1989. Effect of dietary protein level on nitrogen metabolism in the growing bovine: I. Nitrogen recycling and intestinal protein supply in calves. J. Anim. Sci. 67:810-819.

Crompton, L. A., J. A. N. Mills, C. K. Reynolds, and J. France. 2011. Fluctuations in methane emission in response to feeding pattern in lactating dairy cows. Pages 176-180 in Modelling Nutrient Digestion and Utilisation in Farm Animals. D. Sauvant, J. Van Milgen, P. Faverdin, and N. Friggens, ed. Wageningen Academic Publishers, Wageningen, the Netherlands. 10.3920/978-90-8686-712-7_19.

CVB (Centraal Veevoeder Bureau). 2007. Chemical compositions and nutritional values of feed ingredients. Centraal Veevoeder Bureau, Productschap Diervoeder, Den Haag, the Netherlands.

Diaz, M. C., M. E. Van Amburgh, J. M. Smith, J. M. Kelsey, and E. L. Hutten. 2001. Composition of growth of Holstein calves fed milk replacer from birth to 105-kilogram body weight. J. Dairy Sci. 84:830-842.

Dijkstra, J., S. M. van Zijderveld, J. A. Apajalahti, A. Bannink, W. J. J. Gerrits, J. R. Newbold, H. B. Perdok, and H. Berends. 2011. Relationships between methane production and milk fatty acid profiles in dairy cattle. Anim. Feed Sci. Technol. 166:590-595. http://dx.doi.org/10.1016/j.anifeedsci.2011.04.042.

Gerrits, W. J. J., J. Dijkstra, J. M. A. J. Verdonk, G. M. Beelen, and H. Boer. 1999. Effects of ammonia and starch infusion in the colon of preruminant calves. Page 55 in Book of Abstracts of VIII Int. Symp. Protein Metabolism and Nutrition, Aberdeen, UK. G. E. Lobley, A. White, and J.C. MacRae, ed. Wageningen Pers, Wageningen, the Netherlands.

Gerrits, W. J. J., J. W. Schrama, and S. Tamminga. 1998. The marginal efficiency of utilization of all ileal digestible indispensable amino acids for protein gain is lower than 30\% in preruminant calves between 80 and $240 \mathrm{~kg}$ live weight. J. Nutr. 128:1774-1785.

Gerrits, W. J. J., G. H. Tolman, J. W. Schrama, S. Tamminga, M. W. Bosch, and M. W. A. Verstegen. 1996. Effect of protein and protein-free energy intake on protein and fat deposition rates in preruminant calves of 80 to $240 \mathrm{~kg}$ live weight. J. Anim. Sci. 74:2129-2139.

ISO. 1997. Animal feeding stuffs-Determination of nitrogen content and calculation of crude protein content. Kjeldahl method. ISO 5983. Int. Organ. Stand., Geneva, Switzerland.

ISO. 1998a. Animal feeding stuffs, animal products, and faeces or urine-Determination of gross calorific value. ISO 9831. Int. Organ. Stand., Geneva, Switzerland.

ISO. 1998b. Animal feeding stuffs-Determination of moisture and other volatile matter content. ISO 6496. Int. Organ. Stand., Geneva, Switzerland.

ISO. 1999. Animal feeding stuffs-Determination of fat content. ISO 6492. Int. Organ. Stand., Geneva, Switzerland.

ISO. 2002. Animal feeding stuffs - Determination of crude ash. ISO 5984. Int. Organ. Stand., Geneva, Switzerland.

Johnson, K. A., and D. E. Johnson. 1995. Methane emissions from cattle. J. Anim. Sci. 73:2483-2492.

Labussière, E., S. Dubois, J. van Milgen, G. Bertrand, and J. Noblet. 2009a. Effect of solid feed on energy and protein utilization in milk-fed veal calves. J. Anim. Sci. 87:1106-1119. 
Labussière, E., G. Maxin, S. Dubois, J. van Milgen, G. Bertrand, and J. Noblet. 2009b. Effects of feed intake on protein and fat deposition in milk-fed veal calves. Animal 3:557-567.

Labussière, E., J. van Milgen, C. F. M. de Lange, and J. Noblet. 2011. Maintenance energy requirements of growing pigs and calves are influenced by feeding level. J. Nutr. 141:1855-1861.

Marini, J. C., and M. E. Van Amburgh. 2003. Nitrogen metabolism and recycling in Holstein heifers. J. Anim. Sci. 81:545-552.

Mills, J. A. N., J. Dijkstra, A. Bannink, S. B. Cammell, E. Kebreab, and J. France. 2001. A mechanistic model of whole-tract digestion and methanogenesis in the lactating dairy cow: Model development, evaluation, and application. J. Anim. Sci. 79:1584-1597.

NRC. 2000. Nutrient Requirements of Beef Cattle. 7th rev. ed. Natl. Acad. Press, Washington, DC.

Ortigues, I., T. Smith, M. Gill, S. B. Cammell, and N. W. Yarrow. 1990. The effect of fishmeal supplementation of a straw-based diet on growth and calorimetric efficiency of growth in heifers. Br. J. Nutr. 64:639-651.

Reynolds, C. K., and N. B. Kristensen. 2008. Nitrogen recycling through the gut and the nitrogen economy of ruminants: An asynchronous symbiosis. J. Anim. Sci. 86(14 Suppl.):E293-E305.

Rijnen, M. M. J. A., M. W. A. Verstegen, M. J. W. Heetkamp, and J. W. Schrama. 2001. Effects of dietary fermentable carbohydrates on energy metabolism in group-housed sows. J. Anim. Sci. 79:148-154.

SAS Institute. 2000. SAS User's Guide: Statistics. Release 9.20. SAS Inst. Inc., Cary, NC.

Suárez, B. J., C. G. Van Reenen, W. J. J. Gerrits, N. Stockhofe, A. M. Van Vuuren, and J. Dijkstra. 2006. Effects of supplementing concentrates differing in carbohydrate composition in veal calf diets: II. Rumen development. J. Dairy Sci. 89:4376-4386.
Suárez, B. J., C. G. Van Reenen, N. Stockhofe, J. Dijkstra, and W. J. J. Gerrits. 2007. Effect of roughage source and roughage to concentrate ratio on animal performance and rumen development in veal calves. J. Dairy Sci. 90:2390-2403.

van den Borne, J. J. G. C., S. J. J. Alferink, and W. J. J. Gerrits. 2004. Identifying ruminal drinking by measurement of respiratory quotient and methane production in preruminant calves. J. Anim. Sci. 82(Suppl. 1):365. (Abstr.)

van den Borne, J. J. G. C., J. M. A. J. Verdonk, J. W. Schrama, and W. J. J. Gerrits. 2006a. Reviewing the low efficiency of protein utilization in heavy preruminant calves - A reductionist approach. Reprod. Nutr. Dev. 46:121-137.

van den Borne, J. J. G. C., M. W. A. Verstegen, S. J. J. Alferink, R. M. M. Giebels, and W. J. J. Gerrits. 2006b. Effects of feeding frequency and feeding level on nutrient utilization in heavy preruminant calves. J. Dairy Sci. 89:3578-3586.

Van Soest, P. J., J. B. Robertson, and B. A. Lewis. 1991. Methods for dietary fiber, neutral detergent fiber, and nonstarch polysaccharides in relation to animal nutrition. J. Dairy Sci. 74:3583-3597.

Vermorel, M. J. C. Bouvier, and Y. Geay. 1980. Utilisation de l'énergie des aliments par le veau ruminant. Influence de l'apport de lait, du niveau d'alimentation et de l'age du veau. Ann. Zootech. 22:65-68.

Verstegen, M. W. A., and A. Hoogerbrugge. 1987. Climatic condition and health in young farm-animals. Tijdschr. Diergeneeskd. 112:1062-1068.

Zitnan, R. 1998. Influence of dietary concentrate to forage ratio on the development of rumen mucosa in calves. Arch. Anim. Nutr. $51: 279-291$. 